Vladyslav Papusha, senior teacher, Department of Pedagogy, Psychology and Correction Education, Rivne Regional Institute of Postgraduate Pedagogical Education, 74, Chornovola Str., Rivne, Ukraine

\begin{abstract}
ADOLESCENTS' VICTIM BEHAVIOUR: FORMS OF MANIFESTATION AND ANALYSIS
Victim behaviour is peculiar to every person in a greater or lesser extent, regardless of age, sex, and education. It is manifested especially sharply in adolescence, which is characterised by rapid and intense life changes. The highest tendency of adolescents to fall into situations of danger is observed during this period. The aim of the article is a theoretical analysis of the main forms of manifestation of the victim behaviour of adolescents. The theoretical analysis revealed that the issue of victim behaviour can be considered in different aspects. In this study, the term "victim behaviour" denotes a form of adolescents' social activities based on wrong, reckless, immoral, provocative actions, which served as a trigger for committing crimes. The victim behaviour is a deviation from the norms of safe behaviour and is implemented in a set of social, mental, and moral manifestations. Many researchers associate these deviations with the following negative factors which violate the process of socialisation: dissatisfaction with social demands and the presence of such dispositions, which affect the choice of social means and ways of satisfying the needs. There are several groups of adolescents according to the victim behaviour manifestation. The first one includes adolescents with amoral and even unlawful behaviour. They are characterised by such traits as selfishness, rudeness, impatience, etc. The second group of victims involves adolescents who have no clear negative traits but their behaviour can cause or contribute to committing a crime. Along with this, the motives of such behaviour are considered as the adolescents' desire to assert themselves. And the behaviour of adolescents from the third group is considered to be neutral from the standpoint of morality and law. These adolescents are easily influenced by other people; they have no stable skills of moral behaviour, but skills and knowledge which are not their own beliefs.
\end{abstract}

Keywords: adolescent, victim behaviour, forms, types, kinds of manifestations.

Рецензент: д. психол. н., проф. Г. В. Ложкін

Подано до редакиії 17.11.2016

UDC: 159.955 .4

\author{
Zoriana Kovalchuk, \\ Doctor of Psychology, associate professor, professor, \\ Yevhen Karpenko, \\ PhD (Candidate of Psychological Sciences), Associate Professor, \\ Department of Psychology, Lviv State University of Internal Affairs, \\ 26, Horodotska Str., Lviv, Ukraine
}

\title{
REFLECTIVE ACTIVITIES OF AN INDIVIDUAL IN A CRISIS SOCIETY
}

The article reveals the essence of individual's reflective activities as a precondition for favourable personal growth and development of one's economic and general culture. The three basic structural components of the process of reflection in the course of overcoming a crisis have been described. These are fixing the level of personal activity, identifying the causes, evaluating personal efficiency and measures taken in order to overcome crisis consequences. The functions of reflection in a crisis have been examined and are as follows: modelling, organisational, communicative, informative, motivational, and correctional. The author states that there are five levels of human reflective activities which demonstrate comprehension of the best practices and a diverse reflection experience. The intensification of reflective activities leads to an increase in performance and successful overcoming of consequences of a financial and economic crisis; implementation of various life enhancement techniques notwithstanding unfavourable social or economic circumstances becomes more efficient. The article can be of help while training specialists-psychologists, in psycho-counselling, etc.

Keywords: reflection, reflective activities, social strategies, crisis, personal development.

\section{Introduction}

The optimal development of a personality and its subjectness in life is a major factor of civil development and is fulfilled through human reflective activity. It is one of the leading modalities for implementation of genesis of a person, advancement of education and upbringing, personal orientation.

Social strategies in a crisis society are determined by the constructive systematic reflective activities of a modern person. Overcoming negative consequences of a crisis 
depends on one's consciousness, where transformations of the inner world and development take place.

The general scientific and psychological understanding of development is that of a progressive movement toward maturity in terms of reaching its optimal high level; acceptance of subjective nature of development; implementation through contradiction solved by a person; recognition of individual character development in life and professional activity; establishment of the ratio between the potential and actual in personality formation with the focus on revealing the unrealised potential [1].

Studies of reflection were initiated in the works of prominent psychologists B. Ananiev, L. Vygotskiy, V. Davydov, D. Elkonin, and S. Rubinstein, and continued in the studies of modern scientists N. Hutkina, I. Semenov, S. Stepanov, and others. In Ukraine, M. Boryshevsky, S. Vaskivska, S. Maksymenko, V. Yurchenko, T. Yatsenko, and others have made a significant contribution to this aspect of psychology.

The constant need for reflection of people's lives is the main criterion of individual subjectness. For instance, L. Vygotsky based his theoretical approach to the study of reflection, an important component of consciousness, on the psychological development theory [2, p. 232]. According to him, reflection helps to see oneself in the light of one's own feelings [2, p. 245].

O. Kononko believes that reflection is an ability of young people to understand their peculiarities and qualities, regulate their conduct, taking into account possible reactions of others (especially respected people) [3] M. Karnelovych notes that the ability to reflect provides an individual with an opportunity to simultaneously integrate two functions - that of the subject's behaviour and that of the object's control. Integration of these functions is linked inseparably with the ability of an individual to reflect in his/her mind on his/her actual and potential capabilities, the level of adequacy and efficiency of opportunities, awareness of interaction with other people, nature of perceiving oneself as a personality [3, p. 5].

Psychologists assess reflection as a process of understanding one's inner mental acts and states. In particular, social psychologists argue that reflection is not just the self-knowledge and self-understanding of an individual but others' awareness of him. So, it is imaginary reflection of another individual's attitude to an individual. Reflection is a process of mirroring each other, the consciousness of subjects can be inadequate, and thus, distort the image reproduced through reflection. According to O. Bandurko, reflection is the awareness of how the interlocutor perceives an individual; it is a classification of behaviour forms and interpretation of their underlying causes by referring to phenomena already known or unfamiliar or which are responsible for social stereotypes [5, p. 137].

The purpose of the article is outlining the content, functions and levels of reflective activities of an individual in a crisis society.

The purpose involves the following objectives:
1. defining the concept "reflective activities";

2. stating functions of reflective activities in a crisis society;

3. analysing reflection in the process of overcoming a financial, social or economic crisis;

4. determining principal forms of human reflective activities;

5. describing levels of human reflective activities.

To investigate into reflective activities of an individual in a crisis society we resort to theoretical operations such as analysis, synthesis and generalisation which made it possible to identify functions process, levels and forms of reflective activities in a crisis.

\section{Discussion}

The word "reflection" in Latin means "looking back", "representation". Reflection is defined as "...a form of discourse with one's self, an exploration or analysis of possible reasons for engaging in a particular activity" [4] or "an opportunity to examine beliefs about teaching and to use this knowledge to make change to one's practice" (Calderhead, 1989, Clift, Houston, \& Rugach, 1990 in Huang, 2001). The concept of reflection is studied in philosophy, psychology, pedagogy.

Philosophers who deal with the concept of an individual's reflectivity tend to associate it with thoughts about oneself, self-observation, analysis of one's actions, thoughts and emotions, awareness of internality. Reflection is the generation of new knowledge in an individual's mind.

A person acts through reflection. The purpose of reflection is to remember, reveal, fix and understand components and algorithms of activity, namely its content and purpose, types and methods of implementation, final results of activities. Reflection involves the study, research, analysis of the already completed activities. It aims at fixing the causes and consequences of actions which will contribute to effectiveness of this activity in the future [6, p. 289].

Owing to reflection, human interaction with others is improved. It promotes evaluation, critical relationship between a man and his/her activities. Reflection is a source of inner individual experience, the way of selfknowledge and a necessary tool for thinking [6, p. 288].

Reflective activities of an individual are shaped by the education system and teachers as they form a reflective culture of a person. Development is the dominant feature of the pedagogical process, which predominantly involves creation of favourable conditions for selfdevelopment of teachers and students.

The mission of the pedagogical process is to enact positive changes to particular activities, emotions and feelings, knowledge and skills. Reflection in educational psychology implies that you stay as you are, see yourself without illusions and lies, with advantages and disadvantages, give up constant inner fights, calm down and continue your way. Reflection implies that other people are allowed to stay as they are and their uniqueness is recognised and accepted. One should not change others. Reflection is the understanding of what you do not accept; to 
accept reality means to take it unconditionally, to learn from reality. Reflection is the understanding of what you cannot accept in reality, of what prevents you from doing so (fears, bans, judgments, pride, idealised or inadequate representation, unwillingness to change anything) [7, p. 330].

Reflection, which is a source of social strategies in a crisis, involves mutual reflection and assessment of socioeconomic development of oneself and the country. This is a process of an individual's self-identification and interaction with the existing socio-economic situation.

The importance of the socio-economic situation is obvious as it is the relevant social factors that determine the appropriate social activity of a person. The strategies to be employed in a social crisis involve coordination between an individual and his/her own experience. Therefore, reflection in such a process may include the following components: the analysis of one's life, of other individuals' activities, of the current socio-economic situation, the seriousness of the social or financial crisis.

One of the structural elements of personal reflection in a social crisis is the analysis of life genesis. Thus, reflection being a basic component of social policies of a person envisages recording of individual determinants of the professional status, economic activity and development of personal economic culture.

Reflective activity is a precondition for favourable personal growth and development of one's economic and general culture. Thus, we can define functions of reflection in the process of overcoming a social crisis. Reflection turns a person into the subject of activity operating under existing conditions [8, p. 43]. It assists in manifestation of autonomy, self-awareness and professional creativity. The person makes use of chances and possibilities, creates the setting for confidence in his/her own abilities while dealing with different life and economic problems, overcoming a social crisis through reflectivity.

As a rule, reflection performs a diagnostic function, identifying the level of professional economic competence of a person, development of his/her economic culture and consciousness, efficiency of cooperation with others.

Thus, the functions peculiar to reflection of a person in a crisis are as follows:

- Modelling, i.e., projecting of one's professional economic activities, cooperation with others, goal setting; development of ways and means of overcoming a financial crisis in one's own life and the life of family members.

- Organisational, which helps to organise the most productive, constructive, professional activities and interaction with others.

- Communicative, an important prerequisite for dialogic, polylogic communication of the person in the course of professional economic activities, a way to improve business and professional communication.

- Informative, which leads to formation of the meaning in consciousness, visualising the purpose of professional economic activity, ways and methods of crisis overcoming, beneficial cooperation between professionals in this process.
- Motivational, which determines character, direction, performance of professional economic activity, efficiency of actions taken to overcome an economic crisis.

- Correctional, which encourages participants of an economic and financial crisis to correct their activities and interaction depending on the socio-economic situation.

Realisation of these functions contributes to the increase in reflection potential which is formed in the process of overcoming crisis consequences. It also directs an individual's reflective activities under given circumstances.

It is noteworthy that reflection is carried out in the process of substantive (economic, professional) activity (interaction) if is temporarily suspended or upon its completion. A constructive process of personal and professional development, a productive professional interaction with others in any life situation is a successive interchange of reflective activities between their participants [1, p. 289].

Huang Hui-Ju (2001) researches into teachers' preservice reflective practices with the help of their microteaching performances. The results show that participants' reflection comprises eight areas of teaching practice: (1) teaching qualities (82\%), (2) delivery of instructions (78\%), (3) classroom interaction $(40 \%)$, (4) subject matter knowledge (25\%), (5) questioning techniques (23\%), (6) instructional aids (15\%), (7) students (9\%), and (8) general education issues $(4 \%)$. The conclusions of the study point to the need for improvement of reflection content and reflective thinking. The author argues in favour of establishing a support system in teacher training programmes to intentionally engage pre-service teachers in meaningful reflection [9].

The three main structural components form the process of reflection in overcoming a financial, social or economic crisis. They are fixing the level of the economic and financial situation and living conditions; determination of the reasons; evaluation of personal efficiency, taking measures for overcoming crisis consequences.

Realising the fact of crisis itself, a person is able to fix verbally the personal level of development in the process of crisis overcoming. The following areas are:

- Emotional (whether an increase in emotional excitability took place; a person feels positive or negative emotions such as joy, disappointment, satisfaction, frustration, confusion, delight, gratitude, success, etc.; types of emotions)

- Necessity (passive or active state; desire for activity, self-development).

- Motivation (what feelings were caused by the action, interaction, outer and inner motivation, etc.).

- Interests (what interests have appeared, the level of curiosity; educational interests, etc.).

- Value orientations (personal values; the value range enrichment; what the apparent value is).

- Activities (what activities interaction provokes; what activity it corrects; activity rejection; enriching personal experience). 
- Gnostic or research (what happened with knowledge; expansion and deepening of knowledge; systematisation of knowledge, etc.).

- Consciousness (realisation of one's activities; correlation of one's consciousness with the outer environment; self-concept and self-evaluation changes).

- Skills (acquirement of new professional and other skills, etc.).

- Other areas of personality.

The next stage of reflection in the process of crisis overcoming is the determination of causes, among which there are: activity (cooperation) success, activity changes, interesting content, favourable atmosphere of communication, creativity, personal values, importance of solved problems, innovative ways of overcoming a financial and economic crisis, etc.

Thus, a person identifies the cause and effect of the fixed level of his/her economic and financial status and life conditions. The reflection process in overcoming a financial, social or economic crisis comes to an end.

The major criterion in the abovementioned situation is the recognition of the degree of cooperation with others, the level of development, financial economic competence, and the quality of realised activities, interaction in overcoming a financial and economic crisis. Such situation recognition is a way of detecting the level of development, financial and economic competence, emotional state, etc.

It is assumed that actions taken by an individual in order to overcome a crisis form the basis of reflective activities.

A person should understand and use various forms and methods of reflection in the process of reflective activities that correspond to the current socio-economic situation, individual and sexual peculiarities.

Analysing existing reflective practices, it is necessary to identify major forms of reflective activities: verbal (oral); written (graphic), visual, emotional, plastic (motor).

Verbal is one of the main forms of human reflective activities which are depicted in a reflective statement touching upon all major aspects of reflection in the process of overcoming an economic or financial crisis. In accordance with the above, a reflective statement consists of three parts:

1. It begins with the inner awareness of the level of development, a financial and economic situation, life conditions which result from one's own activities and interactions with other people.

2. Then the reasons of the fixed level of development are addressed.

3. The conclusion presupposes evaluation of productivity of one's activities.

The written or graphic reflection form is expressed in the text, which interacts with other ways of overcoming a financial and economic crisis. These texts can be short and concise or quite extended.

Reflection can aptly be presented in the form of colours, drawings, graphs, applications, etc. A person determines his/her state of mind with the help of colours, as- sesses personal daily performance, draws impressions about new events.

An emotional and sensual form of reflection consists in manifestation of an individual's spectrum of feelings and emotions. Quite often this reflection form is accompanied by verbal or other forms of reflective activity.

Institutions of education, in particular secondary schools, as well as qualification-based trainings are responsible for clarifying the process of reflection.

S. Maksymenko states: "In view of his uniqueness and singularity a man was given an ability to reflect upon his own existence. To select, manage, experience, change, and, finally, meet his ultimate goal - that is what human nature is about. And the great drama of human life." [10].

Understanding the best practice, acquiring a diverse reflection experience correlates with different levels of human reflection. Thus, it is possible to single out its several levels on the basis of the structural components of crisis-associated reflection.

The first is the level of fixation, where the subject records only separate parameters, individual characteristics and components. The person does not seek to determine causes of this condition and superficially assesses his/her development as a result of certain activities and interactions.

At the second level - normative - the subjects of reflective activities record their development in progress correlating some of the components with developmental norms and standards. They identify specific causes of the development level and assess their activities and interactions with regard to it.

The third level of reflection - analytical - is characterised by the fact that the subject of reflective activity fixes his/her level of development in various fields; compares it with developmental norms and standards; defines causes underlying development; identifies patterns, trends of activities, problems of personal development, assesses personal development as well as individual components of activities and interactions.

The fourth level - conceptual - represents an attempt to fix the level of reflection development in different fields; identify and analyse the causes of the current development level; identify patterns, trends, activities, interactions; pinpoint issues arising from ongoing activities and interactions; form the concept of development under a financial and economic crisis.

The fifth top level of reflection implies that the subjects overcoming a financial and economic crisis assess the state of their development, activities and interactions in a well-argued manner; they have a deep understanding of the acquired knowledge and skills, and view of the achieved level of development, activities and interactions as personal values. They are capable of forming a comprehensive view of their level of development in various areas, identifying it with developmental standards and criteria, determining the underlying causes, tracing the relationship between the current development level and ongoing activities and interactions. 
Conclusions. Human reflective activities are an intrinsic element of personal development and an efficiency criterion. In a crisis society, they perform modelling, organisational, communicative, informative, motivational and correctional functions.

Reflective activity components essential for overcoming crisis consequences are fixation of one's state and living conditions, evaluation of major determinants; assessment of personal efficiency and actions taken to overcome the crisis.

Reflection is expressed in verbal (oral), written (graphic), visual, emotional and plastic (motor) forms.

\section{ЛІТЕРАТУРА}

1.Бандурка О. М. Основи психології і педагогіки : підручник для вищ. навч. закладів МВС України / О. М. Бандурка, В. О. Тюріна, О. І. Федоренко. - К. : Національний ун-т внутрішніх справ, 2003. - 336 с.

2. Выготский Л. С. Собрание сочинений в 6 т. / Л. С. Выготский. - М. : Педагогика, 1984. - Т.3. $328 \mathrm{c}$.

3. Карнелович М. М. Коммуникативная рефлексия учителей в общении с учащимися / М. М. Карнелович // Веснік Гродзенскага дзяржаунага універсітета імя Я. Купалы. Серыя 4. Правазнуства. Псіхалогія. - 2007. - №2. - С. 1-9.

4. Кононко О. Л. Соціально-емоційний розвиток особистості. - К. : Освіта, 1998. - 255 с.

5. Краевский В. В. Основы обучения. Дидактика и методика / В. В. Краевский, А. В. Хуторской. - 2-е изд., стер. - М. : Изд. центр «Академия», 2008. - 352 с.

6.Крайг Г. Психология развития / Г. Крайг, Д. Бокум. - 9-е изд. - СПб. : Питер, 2005. - 940 с.

\section{REFERENCES}

1. Bandurka, O. M., \& Tiurina, V. O., Fedorenko O. I. (2003). Osnovy psykholohii i pedahohiky: pidruchnyk dlia vyshch. navch. zakladiv MVS Ukrainy [Psychology and Pedagogy: Textbook for higher teaching institutions of the Ministry of internal affairs of Ukraine]. Kyiv: NUVS [in Ukrainian].

2. Vygotskiy, L. S. (1984). Sobranye sochynenyi [Collected works]. (Vols. 3). Moscow: Pedagogika [in Russian].

3. Karnelovich, M. M. (2007). Kommunikativnaya refleksiya uchiteley v obschenii s uchaschimisya [Communicative reflection of teachers in communication with students]. Vesnik Grodzenskaga dzyarzhaunaga universiteta imya Ya. Kupala. Seryya 4. Pravaznaustva. Psikhalogiya - Journal of the Yanka Kupala State University of Grodno. Series 4. Law. Psychology, 2, 1-9 [in Russian].

4. Kononko, O. L. (1998). Sotsialno-emotsiinyi rozvytok osobystosti [Social and emotional development of the individual]. Kyiv: Osvita [in Ukrainian].

5. Kraevskyi, V. V., \& Khutorskoi, A. V. (2008). Osnovy obucheniya. Didaktika i metodika [Fundamentals of teaching. Didactics and methodology]. ( $2^{\text {nd }}$ ed.). Moscow: Izdatelskiy tsentr "Akademiya" [in Russian].
There are five levels of human reflective activities. With each next level overcoming crisis consequences becomes more efficient and implementation of various life enhancement techniques notwithstanding unfavourable socio-economic conditions improves substantially.

Further research is needed to understand the impact reflective activities may exert on personal life formation. Therefore, their connection with emotional competence as an affective component of personal life creation seems to be of academic interest.

7.Шамова Т. И. Управление образовательным процессом в адаптивной школе / Т. И. Шамова, Т. М. Давыденко. - М. : Пед. поиск, 2001. - 384 с.

8. Hatton N. Reflection in teacher education: towards definition and implementation / N. Hatton, D. Smith // Teaching and teacher education / An international journal of research and studies. - 1995. - Vol. 11. - P. 33-49.

9.Huang Hui-Ju. Professional development through reflection : A study of pre-service teachers' reflective practice / Hui-Ju Huang // International Electronic Journal for Leadership in Learning. - 2001. - №5.

10. Kovalchuk Z. Ya. Emotional fortitude of pedagogue as necessary condition of his/her effective cooperation with pupils / Z. Ya. Kovalchuk // II Science, Technology and Higher Education: materials of the II International research and practice conference. - Vol. I. - 2013. - P. 600-603.

11. Maksymenko S. D. Genesis of personality existence / S. D. Maksymenko. - Montreal : Accent Graphics Communication, 2015.

6. Kraig, G., \& Bokum, D. (2005). Psikhologiya razvitiya [Developmental psychology]. $\left(9^{\text {th }}\right.$ ed.). St. Petersburg [in Russian].

7.Shamova, T. I., \& Davydenko, T. M. (2001). Upravleniye obrazovatelnym protsessom $v$ adaptivnoy shkole [Management of educational process in the adaptive school]. Moscow: Ped. poisk [in Russian].

8. Hatton, N., \& Smith, D. (1995). Reflection in teacher education: towards definition and implementation. Teaching and teacher education: an international journal of research and studies, 11, 33-49 [in English].

9.Huang, Hui-Ju (2001). Professional development through reflection: A study of pre-service teachers' reflective practice. International Electronic Journal for Leadership in Learning, 5 [in English].

10. Kovalchuk, Z. Ya. (2013). Emotional fortitude of pedagogue as necessary condition of his/her effective cooperation with pupils. II Science, Technology and Higher Education: Proceedings of the II International research and practice conference. (Vols. I). (pp. $600-$ 603). Westwood [in English].

11. Maksymenko, S. D. (2015). Genesis of personality existence. Montreal: Accent Graphics Communication [in English]. 
Зоряна Ярославівна Ковальчук, доктор психологічних наук, доцент, професор, Євген Володимирович Карпенко, кандидат психологічних наук, доцент, кафедра психології, Львівський державний університет внутрішніх справ, вул. Городоцька, 26, м. Львів, Украӥна

\section{РЕФЛЕКСИВНА ДІЯЛЬНІСТЬ ОСОБИСТОСТІ В УМОВАХ КРИЗОВОГО СУСПІЛЬСТВА}

Оптимальний розвиток особистості, вдосконалення ії суб'єктності як основного чинника розвитку громадянського суспільства здійснюється через рефлексивну діяльність людини. Вона є однією з провідних умов генези особистості, ï вдосконалення, критерієм ефективності процесів навчання та виховання. Таким чином, рефлексивна діяльність актуалізується як на індивідуальному, так і на колективному рівнях, що робить її особливо привабливою для дослідження в контексті сучасних соціально-економічних і ціннісних трансформацій в Україні. Метою статті є розкриття суті рефлексивної діяльності особистості, що перебуває в кризовому суспільстві, та соціальних стратегій іії поведінки. Мета рефлексії полягає в тому, щоб згадати, виявити, зафіксувати й усвідомити компоненти й алгоритм діяльності: ії зміст і призначення, типи, способи здійснення, проблеми реалізації діяльності та шляхи їх вирішення, отримані результати тощо. Рефлексія передбачає вивчення, дослідження, аналіз суб’єктом уже реалізованої, здійсненої діяльності. В умовах кризового суспільства вона виконує наступні функції: проектувальну; організаторську; комунікативну, змістову; мотиваційну; корекційну. Рефлексивна діяльність складається з трьох провідних структурних компонентів, які використовуються в процесі подолання людиною наслідків кризи: фіксування свого стану, умов життєдіяльності; визначення основних детермінант; оцінка продуктивності своєї діяльності, застосованих заходів щодо подолання наслідків кризи. Серед основних форм рефлексивної діяльності людини можемо виділити наступні: вербальну (усну), письмову (графічну), образотворчу, емоційно-чуттєву, пластичну (рухову). Існують також п'ять рівнів рефлексії діяльності людини. По мірі іх зростання збільшується продуктивність та успішність подолання наслідків економічної кризи, ефективнішою стає реалізація різних соціальних технологій $з$ оптимізації життєдіяльності індивіда в будь-якій соціально-економічній ситуації. На першому рівні суб'єкт тільки фіксує окремі параметри, характеристики, компоненти свого розвитку. На другому - співвідносить їх із нормою, еталоном. Третій рівень характеризується повною і критичною фіксацією суб'єктом рефлексивної діяльності свого розвитку в різних сферах, виявленням його детермінант, закономірностей тощо. Носіям четвертого рівня, крім переліченого, притаманне створення концепції власного розвитку в умовах подолання наслідків соціальноекономічної кризи. П'ятому, найвищому, рівневі рефлексії відповідає також глибоке усвідомлення набутих знань, умінь, досягнутого рівня розвитку, здійснюваної діяльності, взаємодії як особистісних цінностей.

Ключові слова: рефлексія, рефлексивна діяльність, соціальні стратегії, криза, розвиток особистості.

Зоряна Ярославовна Ковальчук, доктор психологических наук, дочент, профессор, Евгений Владимирович Карпенко, кандидат психологических наук, доцент, кафедра психологии, Львовский государственный университет внутренних дел, ул. Городоикая, 26, г. Львов, Украина

\section{РЕФЛЕКСИВНАЯ ДЕЯТЕЛЬНОСТЬ ЛИЧНОСТИ В УСЛОВИЯХ КРИЗИСНОГО ОБЩЕСТВА}

Оптимальное развитие личности, совершенствование ее субъектности как основного фактора развития гражданского общества осуществляется посредством рефлексивной деятельности человека. Она является одним из ведущих условий генезиса личности, ее совершенствования, критерием эффективности процессов обучения и воспитания. Таким образом, рефлексивная деятельность актуализируется как на индивидуальном, так и на коллективном уровнях, что делает ее особенно привлекательной для исследования в контексте современных социально-экономических и ценностных трансформаций в Украине. Целью статьи является раскрытие сущности рефлексивной деятельности личности, находящейся в кризисном обществе, и социальных стратегий её поведения. Цель рефлексии заключается в том, чтобы вспомнить, обнаружить, зафиксировать и понять компоненты и алгоритм деятельности: ее содержание и назначение, типы, способы осуществления, проблемы реализации деятельности и пути их решения, полученные результаты и т. п. Рефлексия предполагает изучение, исследование, анализ субъектом уже реализованной, осуществленной деятельности. В условиях кризисного общества она выполняет следующие функции: проектировочную; организаторскую; коммуникативную, содержательную; мотивационную; коррекционную. Рефлексивная деятельность состоит из трех ведущих структурных компонентов, которые используются в процессе преодоления человеком последствий кризиса: фиксирование своего состояния, условий жизнедеятельности; определение основных детерминант; оценка продуктивности своей дея- 
тельности, предпринимаемых мер по преодолению последствий кризиса. Среди основных форм рефлексивной деятельности человека можем выделить следующие: вербальную (устную), письменную (графическую), изобразительную, эмоционально-чувственную, пластическую (двигательную). Существуют также пять уровней рефлексивной деятельности человека. По мере их роста увеличивается продуктивность и успешность преодоления последствий экономического кризиса, более эффективной становится реализация различных социальных технологий по оптимизации жизнедеятельности индивида в любой социально-экономической ситуации. На первом уровне субъект только фиксирует отдельные параметры, характеристики, компоненты своего развития. На втором - соотносит их с нормой, эталоном. Третий уровень характеризуется полной и критической фиксацией субъектом рефлексивной деятельности своего развития в различных сферах, выявлением его детерминант, закономерностей и т. п. Носителям четвертого уровня, кроме перечисленного, присуще создание концепции собственного развития в условиях преодоления последствий социально-экономического кризиса. Пятому, самому высокому уровню рефлексии, соответствует также глубокое осознание приобретенных знаний, умений, достигнутого уровня развития, осуществляемой деятельности, взаимодействия как личностных ценностей.

Ключевые слова: рефлексия, рефлексивная деятельность, социальные стратегии, кризис, развитие личности.

Подано до редакиіï 18.11.2016

УДК: 159.9.019.4+616-008.811.9

Анастасія Миколаӥвна Яцишина, аспірант кафедри теорії та методики практичної психології, Південноукраїнський національний педагогічний університет імені К. Д. Уиинського, вул. Фонтанська дорога, 4, м. Одеса, Украӥна

\section{ДОСЛІДЖЕННЯ ПСИХОЛОГІЧНИХ ОСНОВ ДЕСТРУКТИВНОї ПОВЕДІНКИ ТА ЇЇ ПРОЯВУ У ДІТЕЙ ШКІЛЬНОГО ВІКУ}

Роботу присвячено вивченню психологічних основ деструктивної поведінки та ї̈ прояву у дітей шкільного віку. Аналізуються три етапи в історії пізнання психологічних проявів деструктивної поведінки особистості: донауковий етап, осмислення механізмів деструктивної поведінки та иляхів ї̈ подолання та науковий етап. Деструктивна поведінка розглядається як процес неадекватних руйнівних дій, спрямованих на ускладнення взаємодії особистості з сочіальним оточенням. Указуються методи і технології профілактики деструктивних дій. У результаті емпіричного дослідження виявлено суттєві ознаки деструктивної поведінки учнів.

Ключові слова: деструктивна поведінка, деструкція, неадекватні дї̈, діти шкільного віку.

Психологічні особливості деструктивної поведінки учнів молодшого шкільного віку останнім часом стають предметом аналізу різних фахівців (як психологів, так і педагогів) [11]. Актуальність цієї проблеми обумовлена, перш за все, недостатньою опрацьованістю психологічних механізмів та інших феноменів, які обумовлюють дії, прояв та зміну деструктивної поведінки. Існують дані, в яких зроблено спробу дослідити цю особливість. Переважна більшість досліджень в цьому аспекті зорієнтовані на нівелювання деструктивних дій засобами різних технологій $[13 ; 19]$.

Також є дані про різні деструктивні прояви в поведінці сучасних дітей шкільного віку, що вказують на тенденцію зміни поведінки із часом та набуття стійких рис [13]. Проведений аналіз засвідчив, що виникнення деструктивної поведінки може обумовлюватися як суто психологічними та динамічними особливостями, так і особистісними. До останніх відносять: схильність до агресії, підвищення роздратованості, збудливість та ін. [7].

У той же час, як вказують наші спостереження деструктивної поведінки учнів молодших класів, вона $\epsilon$ досить поширеним явищем, що ускладнює навчально-виховний процес.

Мета статті - дослідити психологічні особливості деструктивної поведінки на рівні ії змісту та технології корекції.

Для вирішення заданої мети було поставлено наступні завдання: узагальнити дані про дослідження деструктивної поведінки дітей; уточнити зміст та ознаки деструктивної поведінки молодших школярів; розкрити та систематизувати існуючі психологічні технології корекції деструктивної поведінки дітей.

Вирішуючи перше завдання, на основі узагальнення різних даних нами умовно виділено кілька етапів у пізнанні проблеми деструктивної поведінки в історичному контексті.

Перший етап (IV в. до н. е. - XVII в. до н. е.), умовно названий нами як донауковий, засвідчив, що проблема деструктивної поведінки людини привертала до себе увагу зі стародавніх часів. У християнсь- 